\title{
Insulin-like growth factor binding protein-3 has dual effects on gastrointestinal stromal tumor cell viability and sensitivity to the anti-tumor effects of imatinib mesylate in vitro Jheri J Dupart ${ }^{1,5}$, Jonathan C Trent ${ }^{2,5}$, Ho-Young Lee ${ }^{3,5}$, Kenneth R Hess
Andrew K Godwin'
}

Address: ${ }^{1}$ Department of Pathology, the University of Texas M.D. Anderson Cancer Center, Houston, Texas, USA, ${ }^{2}$ Department of Sarcoma Medical Oncology, the University of Texas M.D. Anderson Cancer Center, Houston, Texas, USA, ${ }^{3}$ Department of Head and Neck Thoracic Oncology, the University of Texas M.D. Anderson Cancer Center, Houston, Texas, USA, ${ }^{4}$ Department of Biostatistics, the University of Texas M.D. Anderson Cancer Center, Houston, Texas, USA, ${ }^{5}$ Graduate School of Biomedical Sciences, the University of Texas Health Science Center at Houston, Houston, Texas, USA, ${ }^{6}$ Department of Medical Oncology, Fox Chase Cancer Center, Philadelphia, Pennsylvania, USA and ${ }^{7}$ Department of Human Health and Medical Science, Kochi University, Nankoku, Kochi, Japan

Email: Jheri J Dupart - jjdupart@mdanderson.org; Jonathan C Trent - jtrent@mdanderson.org; Ho-Young Lee - hlee@mdanderson.org; Kenneth R Hess - khess@mdanderson.org; Andrew K Godwin - Andrew.Godwin@fccc.edu; Takahiro Taguchi - ttaguchi@med.kochi-ms.ac.jp; Wei Zhang* - wzhang@mdanderson.org

* Corresponding author

Published: 10 November 2009

Molecular Cancer 2009, 8:99 doi:10.1 186/1476-4598-8-99
Received: 13 March 2009

Accepted: 10 November 2009

This article is available from: http://www.molecular-cancer.com/content/8/I/99

(c) 2009 Dupart et al; licensee BioMed Central Ltd.

This is an Open Access article distributed under the terms of the Creative Commons Attribution License (http://creativecommons.org/licenses/by/2.0), which permits unrestricted use, distribution, and reproduction in any medium, provided the original work is properly cited.

\begin{abstract}
Background: Imatinib mesylate has significantly improved survival and quality of life of patients with gastrointestinal stromal tumors (GISTs). However, the molecular mechanism through which imatinib exerts its anti-tumor effects is not clear. Previously, we found up-regulation of insulin-like growth factor binding protein-3 (IGFBP3) expression in imatinib-responsive GIST cells and tumor samples. Because IGFBP3 regulates cell proliferation and survival and mediates the anti-tumor effects of a number of anti-cancer agents through both IGF-dependent and IGF-independent mechanisms, we hypothesized that IGFBP3 mediates GIST cell response to imatinib. To test this hypothesis, we manipulated IGFBP3 levels in two imatinib-responsive GIST cell lines and observed cell viability after drug treatment.
\end{abstract}

Results: In the GIST882 cell line, imatinib treatment induced endogenous IGFBP3 expression, and IGFBP3 down-modulation by neutralization or RNA interference resulted in partial resistance to imatinib. In contrast, IGFBP3 overexpression in GIST-TI, which had no detectable endogenous IGFBP3 expression after imatinib, had no effect on imatinib-induced loss of viability. Furthermore, both the loss of IGFBP3 in GIST882 cells and the overexpression of IGFBP3 in GIST-TI cells was cytotoxic, demonstrating that IGFBP3 has opposing effects on GIST cell viability.

Conclusion: This data demonstrates that IGFBP3 has dual, opposing roles in modulating GIST cell viability and response to imatinib in vitro. These preliminary findings suggest that there may be some clinical benefits to IGFBP3 therapy in GIST patients, but further studies are needed to better characterize the functions of IGFBP3 in GIST. 


\section{Introduction}

Gastrointestinal stromal tumors (GISTs) are the most common mesenchymal tumors of the digestive tract. GIST pathogenesis is most frequently attributed to gain-offunction mutations in the receptor tyrosine kinase KIT; however, activating mutations in platelet derived growth factor receptor- $\alpha$ (PDGFRA) have been observed in GISTs with wild-type KIT [1]. This trend of oncogenic KIT or PDGFRA expression is observed in approximately $85 \%$ of tumors $[2,3]$. Traditionally, surgery was the only successful therapeutic strategy; however, patients with unresectable or metastatic disease survived only a median of 18-24 months after diagnosis $[4,5]$. Those patients with widespread metastatic disease have an estimated 9 month overall survival [6]. The development of the selective kinase inhibitor imatinib mesylate (also known as Gleevec) has dramatically altered the treatment strategies for GIST and other cancers.

An ATP mimetic, imatinib competitively occupies the ATP binding pocket of target kinases, thereby preventing their activation [7]. Although designed to specifically target PDGFR, imatinib also effectively inhibits KIT and Abl kinases, which have structurally similar ATP binding pockets [8]. Thus, imatinib is successful as a targeted therapy in GIST through inhibition of KIT or PDGFRA, and in other cancers, including Philadelphia chromosome-positive chronic myelogenous leukemias through inhibition of Bcr-Abl [9]. Clinical studies with imatinib have reported objective response rates of $50-70 \%$ and an estimated median survival of 57 months in patients with advanced GIST [10]. However, some GIST patients fail to respond or become resistant to imatinib therapy $[9,11]$. Therefore, to further improve GIST patient survival, it is imperative to gain a better understanding of the underlying molecular mechanisms of imatinib-induced GIST cell cytotoxicity.

In a previous study to determine how imatinib exerts its anti-tumor effects, we demonstrated that insulin-like growth factor binding protein-3 (IGFBP3) expression is up-regulated after imatinib treatment in the imatinibresponsive GIST cell line GIST882 as well as KIT-expressing tumor samples [12]. IGFBP3, a member of the insulinlike growth factor binding protein family, is a multifunctional protein that directly binds and regulates the mitogenic and anti-apoptotic actions of the insulin-like growth factors (IGFs) [13]. IGFBP3 also has IGF-independent growth inhibitory and pro-apoptotic effects, which may be mediated through cell surface [14] or nuclear receptors [15-17]. Furthermore, expression of IGFBP3 is induced by a number of growth inhibitory and pro-apoptotic agents, including p53 [18,19], TGF- $\beta$ $[20,21]$, retinoids [20], TNF- $\alpha$ [22], vitamin D [23], and celecoxib [24], suggesting that IGFBP3 may, in part, mediate their anti-tumor effects.

Having identified IGFBP3 as a candidate imatinib-targeted gene, we sought to determine whether IGFBP3 directly mediates the cytotoxicity of imatinib in GIST cells. In this study, we manipulated IGFBP3 levels in two imatinib-responsive GIST cell lines and observed cell viability after drug treatment. We found that IGFBP3 down-regulation in GIST882 cells resulted in a loss of cell viability and partial resistance to imatinib. In contrast, IGFBP3 overexpression was cytotoxic but did not enhance or abrogate the cytotoxic effects of imatinib in GIST-T1 cells. Thus, IGFBP3 has cell-dependent effects on GIST cell viability and in mediating imatinib response.

\section{Results \\ Heterogeneous induction of IGFBP3 after imatinib in GIST cell lines}

To study the role of IGFBP3 in GIST, we used two available GIST cell lines: GIST882 and GIST-T1. The GIST882 cell line harbors a missense mutation in KIT exon 13 (K642E) affecting the kinase domain. Imatinib treatment of GIST882 cells results in a loss of viability of up to $40 \%$ with doses as low as $0.1 \mu \mathrm{M}$, but the response appeared to reach a plateau, as higher doses of imatinib had no additional effect on cell viability (Figure 1A). Imatinib treatment induced endogenous IGFBP3 expression by 24 hours after treatment, and the induction was maintained at 48 hours post-treatment (Figure 1B). Because IGFBP3 is a secreted protein that can be re-internalized into the cell [25], we used an ELISA to determine if elevated levels of IGFBP3 were also present in the cell culture medium after imatinib exposure. As shown in Figure 1C, imatinib treatment significantly increased the concentration of IGFBP3 in the conditioned medium, consistent with imatinibinduced IGFBP3 up-regulation and secretion by GIST882 cells. The GIST-T1 cell line has an in-frame deletion of 57 nucleotides in KIT exon 11 (V560delY579) affecting the juxtamembrane regulatory domain. Imatinib treatment resulted in a loss of viability of more than $60 \%$ at a concentration of $0.5 \mu \mathrm{M}$, and the observed $\mathrm{IC}_{50}$ was $0.05 \mu \mathrm{M}$ at 48 and 72 hours (Figure 1D). In contrast to GIST882 cells, GIST-T1 cells did not have detectable basal levels of IGFBP3, nor did imatinib treatment induce IGFBP3 expression (Figure 1E). This data was a preliminary indicator that IGFBP3 induction is not required for GIST-T1 cell response to imatinib. However, imatinib-induced IGFBP3 expression in the relatively more resistant GIST882 cells suggested that IGFBP3 might contribute to a resistance phenotype.

IGFBP3 has cell-dependent effects on viability in GIST cells Before we evaluated whether IGFBP3 modulates GIST cell response to imatinib, we first sought to determine what 
GIST882

KIT exon 13: K642E

A

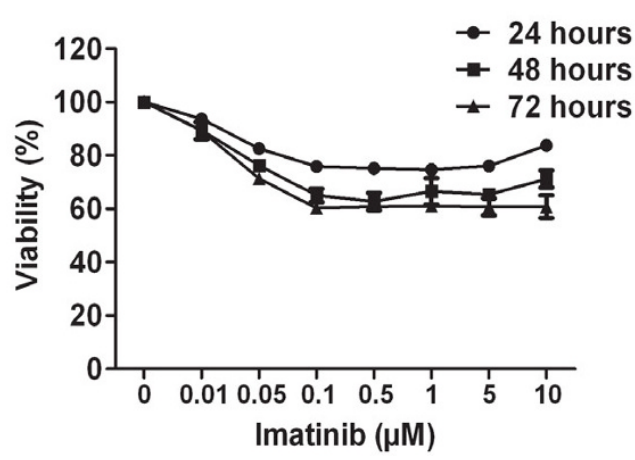

B

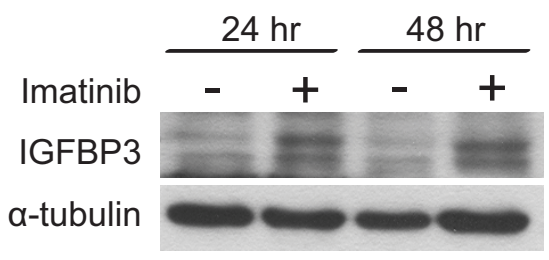

C

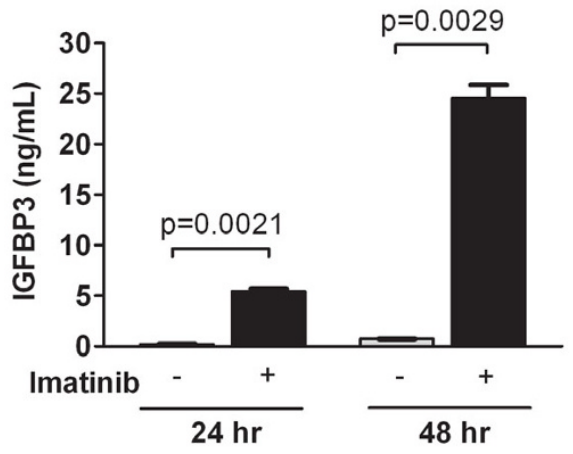

GIST-T1

KIT exon 11: V560delY579

D
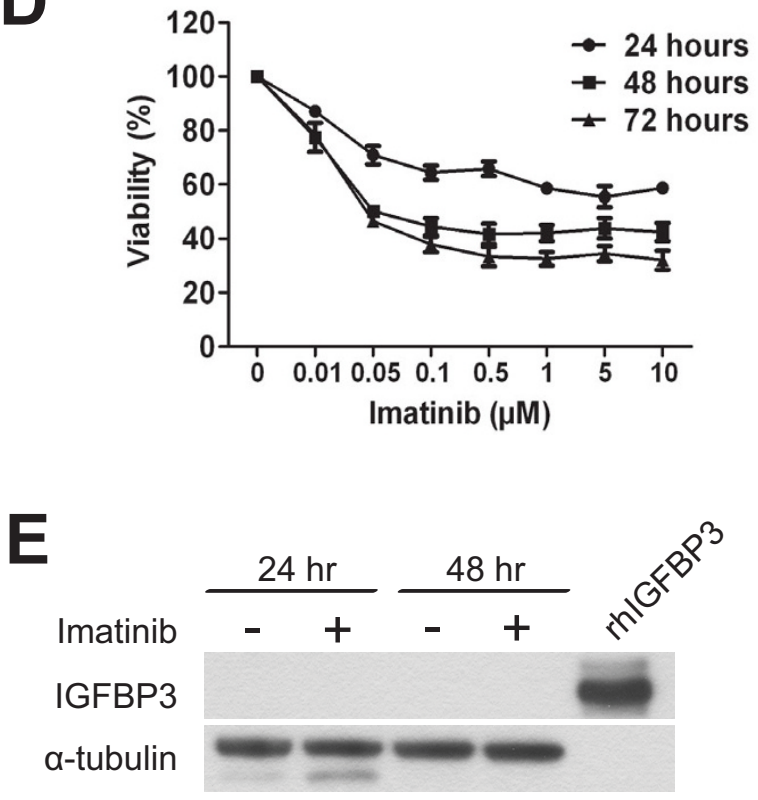

\section{Figure I}

Imatinib-induced IGFBP3 expression is heterogenous in GIST cells. GIST882 (A) or GIST-TI (D) cells were treated with different doses of imatinib for 24,48 , or 72 hours and then analyzed with the MTS assay to determine cell viability. After treatment with I $\mu$ M imatinib for 24 or 48 hours, whole cell lysates isolated from GIST882 (B) or GIST-TI (E) were analyzed for IGFBP3 expression by immunoblotting, or (C) conditioned medium from GIST882 cells analyzed for IGFBP3 levels by ELISA. rhIGFBP3, recombinant human IGFBP3.

effects IGFBP3 itself has in the two GIST cell lines. Because GIST882 cells have detectable levels of endogenous cellular and secreted IGFBP3, we down-modulated IGFBP3 using either a blocking antibody to sequester secreted IGFBP3 or an siRNA knockdown approach. Both IGFBP3 neutralization using a blocking antibody (Figure 2A) and knockdown using RNA interference (Figure 2B) resulted in a significant loss of cell viability, suggesting that IGFBP3 is required for GIST882 cell survival. In contrast, as GIST-T1 cells have no detectable endogenous IGFBP3, we overexpressed IGFBP3 using an adenoviral gene expression system. Infection with an adenoviral vector expressing IGFBP3 (Ad-IGFBP3) but not empty vector (Ad-EV) resulted in high, sustainable levels of IGFBP3 (Figure 3A). IGFBP3 overexpression in GIST-T1 cells resulted in a dose-dependent loss of cell viability as observed 3 (Figure 3B) and 5 days (Figure 3C) post adenoviral infection. These results show that IGFBP3 overex- 
A

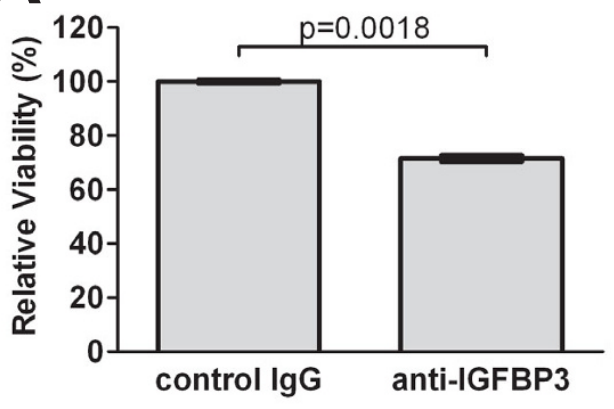

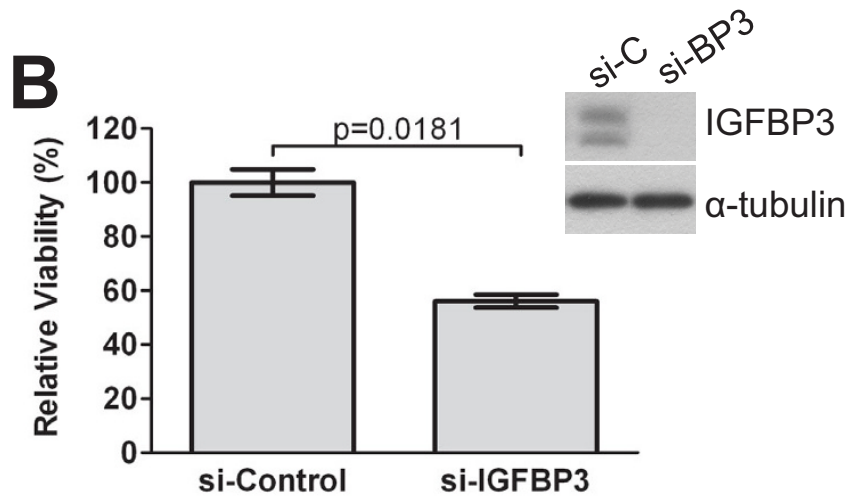

Figure 2

Effect of IGFBP3 knockdown or neutralization on GIST882 cell viability. (A) GIST882 cells were treated with IGFBP3 blocking antibody (anti-IGFBP3) or control $\operatorname{lgG}(4 \mathrm{ug} / \mathrm{mL})$ for 48 hours before cell viability was measured with the MTS assay. (B) GIST882 cells were transfected with siRNA duplexes specific to IGFBP3 (si-IGFBP3) or mismatch sequence (si-Control) and subsequently treated with imatinib ( $\mathrm{I} M \mathrm{M})$ for 48 hours. Cell viability was assessed with the MTS assay. Immunoblotting shows IGFBP3 expression after si-Control (si-C) or si-IGFBP3 (si-BP3) transfection.

pression reduces cell viability in GIST-T1 cells Collectively, our data demonstrate that IGFBP3 has dual, opposing cell line-dependent effects on GIST cell survival.

\section{IGFBP3 modulation alters GIST cell sensitivity to imatinib in a cell-dependent manner}

The above studies show a complex pattern of IGFBP3 function in regulating GIST cell survival. To determine whether IGFBP3 contributes to GIST cell response or resistance to imatinib, we modulated IGFBP3 protein levels in GIST882 and GIST-T1 cells and assayed for potential changes in imatinib sensitivity. Because IGFBP3 is a secreted protein that can be re-internalized into the cell [25], we first used an IGFBP3 blocking antibody to sequester secreted IGFBP3 in the culture medium. GIST882 cells were simultaneously treated with imatinib and different concentrations of IGFBP3 blocking antibody (anti-IGFBP3) or control IgG and viability assessed with the MTS assay. Treatment with anti-IGFBP3 alone significantly reduced cell viability ( $\mathrm{p}=0.0018$ ) relative to control IgG (Figure 4A). To determine the effects IGFBP3 neutralization on imatinib sensitivity, MTS data were analyzed with a two-way ANOVA (interaction: p < 0.0001). As shown in Figure 4A, imatinib significantly reduced viability in both cells treated with anti-IGFBP3 or control IgG; however imatinib was significantly less cytotoxic in the presence of anti-IGFBP3. Because IGFBP3 is also localized intracellularly, we used RNA interference to suppress drug-induced IGFBP3 expression. As shown in Figure 4B, si-IGFBP3 effectively reduced IGFBP3 mRNA levels in untreated cells and also prevented IGFBP3 induction after imatinib exposure. Loss of IGFBP3 protein expression after imatinib was also observed (Figure 4C). Using this
siRNA, we investigated whether inhibiting IGFBP3 expression altered GIST882 cell sensitivity to imatinib. IGFBP3 knockdown itself was cytotoxic to GIST882 cells ( $\mathrm{p}=$ 0.018) (Figure 4D). We further analyzed the effects of IGFBP3 expression on GIST882 cell sensitivity to imatinib with a two-way ANOVA (interaction: $\mathrm{p}=0.0243$ ). As demonstrated in Figure 4D, imatinib treatment significantly reduced viability in si-IGFBP3 or si-Control transfected cells; however, cells with reduced IGFBP3 expression were partially resistant to the cytotoxic effects of imatinib. Taken together, this data suggests that IGFBP3 sensitizes GIST882 cells to the anti-tumor effects of imatinib.

In contrast to GIST882 cells, GIST-T1 cells have no endogenous IGFBP3 expression and there was no induction of IGFBP3 after imatinib treatment. Therefore, this IGFBP3negative cell line provided us a system to examine the effects of IGFBP3 on imatinib response using a gain-offunction approach. To test whether IGFBP3 expression altered GIST-T1 sensitivity to imatinib, cells infected with Ad-IGFBP3 or Ad-EV or mock infected were subsequently analyzed for changes in cell viability after imatinib. AdIGFBP3 infection alone was cytotoxic relative to Ad-EV at 25 moi $(p=0.0024)$ (Figure 5). Analyzing imatinib sensitivity after IGFBP3 overexpression with a two-way ANOVA (interaction: $\mathrm{p}=0.0009$ ), we observed that imatinib significantly reduced viability in cells infected with AdIGFBP3 or Ad-EV. Furthermore, IGFBP3 overexpression did not significantly alter imatinib sensitivity in GIST-T1 cells (Figure 5). Although IGFBP-3 is cytotoxic to GIST-T1 cells, our data suggests that IGFBP3 does not mediate GIST-T1 response to imatinib. 


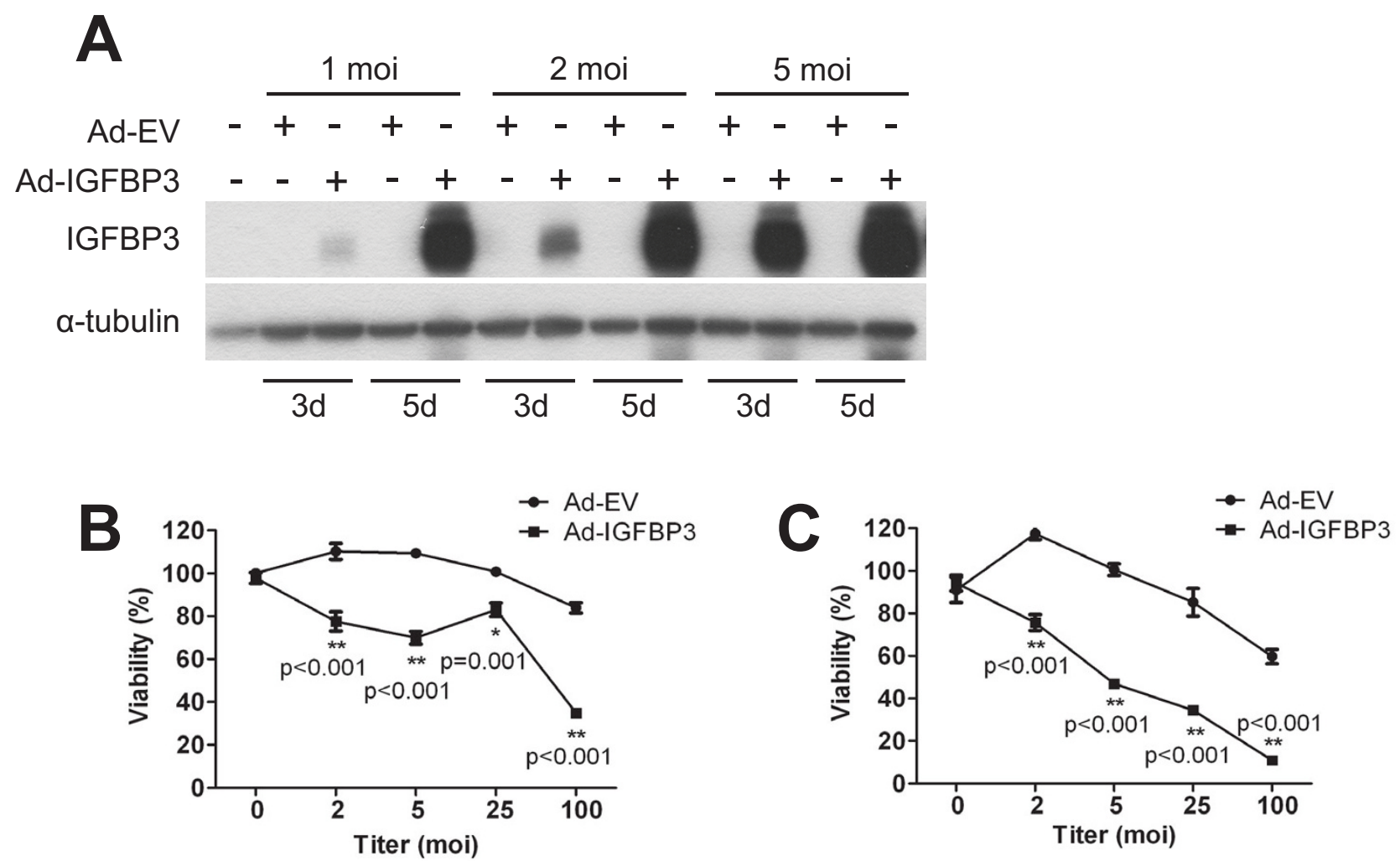

Figure 3

Effect of IGFBP3 overexpression on GIST-TI cell viability. (A) Whole cell lysates isolated from GIST-TI cells three or five days after mock infection or infection with indicated titers (moi) of adenovirus expressing IGFBP3 (Ad-IGFBP3) or empty vector (Ad-EV) were analyzed by immunoblotting for IGFBP3 expression. Viability of GIST-TI cells mock infected or infected with indicated titers of Ad-EV or Ad-IGFBP3 was analyzed 3 days (B) or 5 days (C) post-infection with the MTS assay. Asterisks $\left.{ }^{*}\right)$ denote significant differences in cell viability at the indicated doses of Ad-EV vs. Ad-IGFBP3.

\section{Discussion}

In this study, we examined the potential role of IGFBP3 as a mediator of the therapeutic effects of imatinib mesylate in GISTs. Our previous studies showed that IGFBP3 is upregulated after imatinib treatment in a responsive GIST cell line (GIST882), and we provide evidence that IGFBP3 does indeed partially mediate GIST882 cell response to imatinib in vitro. In contrast, IGFBP3 has no effect on imatinib sensitivity in the responsive GIST-T1 cell line, which has no detectable endogenous IGFBP3 levels before or after imatinib exposure. Further, our studies, using both gain-of-function and loss-of-function approaches, reveal that IGFBP3 is an important modulator of cell viability in GISTs, but the effect is cell-dependent. Similar to what has been reported for epithelial cancers [23,26-34], IGFBP3 also manifests dual functions on cell survival in GIST, a mesenchymal cancer.

Up-regulation of IGFBP3 has been observed in response to a variety of anti-cancer agents [18-23], including celecoxib [24]. In addition, IGFBP3 potentiates the action of paclitaxel [35] and sensitizes cancer cells to the cytotoxic effects of gefitinib [36] and other chemotherapeutic agents [37]. Because we observed IGFBP3 expression in GIST in response to imatinib [12], we hypothesized that IGFBP3 would mediate its anti-tumor effects. After manipulating IGFBP3 levels in two GIST cell lines, we observed a modulating effect on response in GIST882, suggesting that the induction of IGFBP3 is a significant, specific response to imatinib-induced stress. Failure to observe a similar response in GIST-T1 suggested that GIST-T1 cells are insensitive to IGFBP3. However, additional studies showed that IGFBP3 regulates GIST cell viability with opposing effects. Overexpression of IGFBP3 in GIST-T1 cells, which have no detectable endogenous IGFBP3 expression before or after imatinib, results in a loss of cell viability, demonstrating that IGFBP3 has growth inhibitory effects in this cell line. In contrast, we expected that the loss of IGFBP3 by neutralization or knockdown in GIST882 cells, which have increased IGFBP3 expression after imatinib, would have a protective effect on cell viability. However, our data shows that 
A

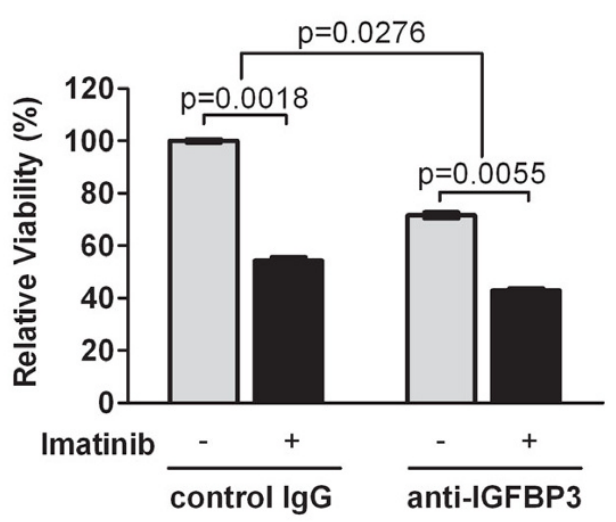

B

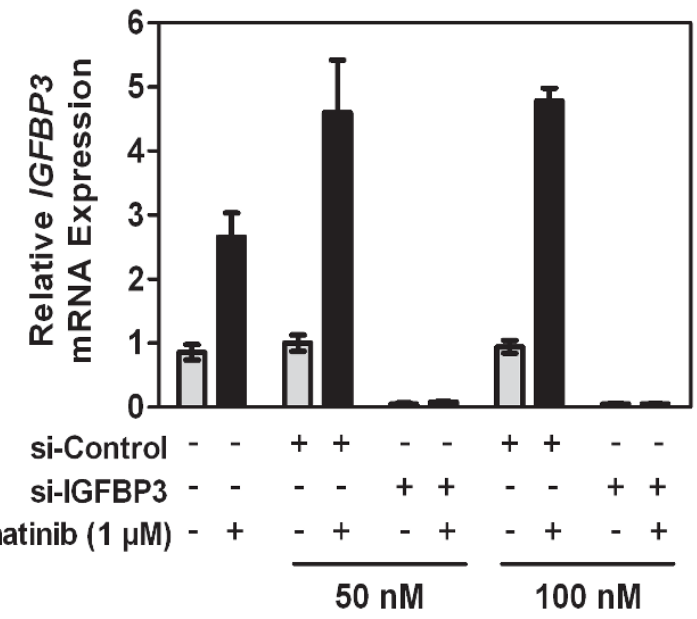

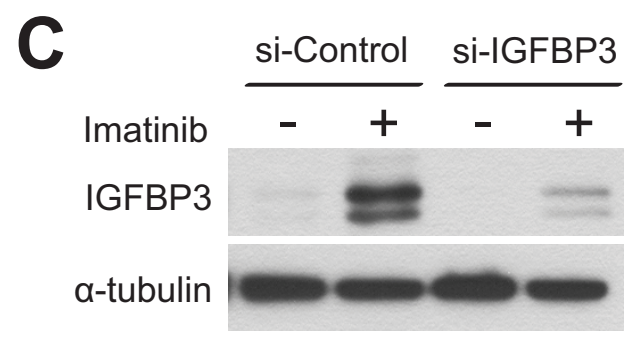

D

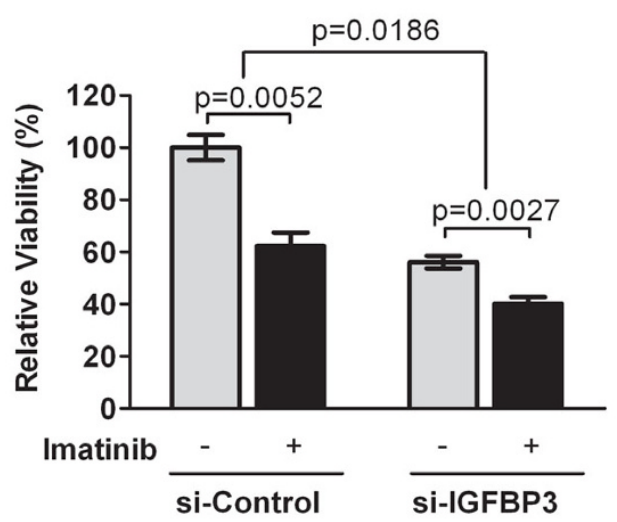

\section{Figure 4}

Effect of IGFBP3 neutralization or knockdown on GIST882 response to imatinib. (A) Cells were treated simultaneously with imatinib $(I \mu \mathrm{M})$ and anti-IGFBP3 or control $\operatorname{lgG}(4 \mu \mathrm{g} / \mathrm{mL})$ for 48 hours, and viability was assessed with the MTS assay. (B) RNA was extracted from ST882 cells after transfection with of siRNA (50 or $100 \mathrm{nM}$ ) and imatinib (I $\mu$ M) for 48 hours. After the reverse transcriptase reaction, IGFBP3 mRNA levels were quantified by real-time PCR. (C)Whole cell lysate isolated after siRNA $(50 \mathrm{nM})$ transfection and imatinib $(\mathrm{I} \mu \mathrm{M})$ treatment were analyzed for IGFBP3 expression by immunoblotting. (D) Viability after siRNA $(50 \mathrm{nM})$ transfection and imatinib treatment $(I \mu M)$ was assessed by MTS.

IGFBP3 down-modulation is cytotoxic, demonstrating that IGFBP3 is necessary for cell viability. Thus, in GIST882, IGFBP3 has two distinct roles, which may be attributed to a dose-dependent mechanism. Dual functions of IGFBP3 have been reported previously in cancers of the renal cells [26,27], esophagus [28,29], breast $[30,31]$, colon $[32,33]$, and prostate $[23,34]$, as well as in endothelial cells [38]. The mechanism that determines the final outcome of IGFBP3 action is not well understood, though some studies suggest a role for post-translational modification [39], localization within specific cellular compartments $[25,40]$, extracellular matrix composition [41], or binding partner interaction $[15,42,43]$. Despite its dual effects on GIST cell viability, IGFBP3 appears to exert its effects through a KIT-independent mechanism, as imatinib-induced KIT inactivation has no effect on IGFBP3-mediated loss of cell viability in either GIST882 or GIST-T1 cells.

IGFBP3 expression is lost in many cancer cells [44-46], and reintroduction of the protein often results in cell death $[21,46,47]$. Similarly, our results show that IGFBP3 expression is not detectable in GIST-T1 cells but overexpression leads to loss of cell viability. Indeed, the growth inhibitory and pro-apoptotic effects of IGFBP3 are well established in a variety of in vitro and in vivo cancer models. On the other hand, IGFBP3 also has growth stimulatory effects $[29,33,34,38,41,48]$, depending on the cell type and context. Further, increased IGFBP3 expression has also been linked to renal cell carcinoma [27], breast 


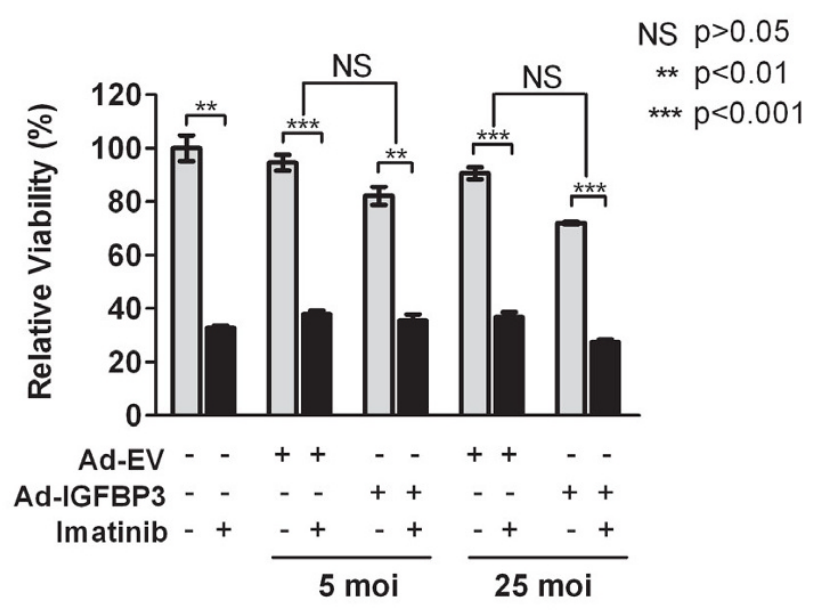

Figure 5

Effect of IGFBP3 overexpression on GIST-TI cell sensitivity to imatinib. GIST-TI cells were mock infected or infected with indicated titers (moi) of Ad-IGFBP3 or AdEV. The following day, infected cells were exposed to imatinib $(0.075 \mu \mathrm{M})$ for 48 hours. Viability was assessed with the MTS assay. NS, not significant.

cancer [31,49], and metastatic melanoma [50], suggesting that IGFBP3 may contribute to tumorigenesis or disease progression. Here, we report that GIST882 cells, which have detectable IGFBP3 protein expression, require IGFBP3 for cell viability, confirming the notion that IGFBP3 may facilitate cancer cell proliferation and survival. Complete understanding of IGFBP3 requires investigations of its binding partners, post-translational modifications, and signal transduction pathways in vitro and in vivo.

One possible pathway through which IGFBP3 may exert its effects in GISTs is the IGF pathway. A number of recent studies have explored the IGF axis for prognostic and therapeutic value in GISTs. Braconi and colleagues reported that expression of IGF-1 and IGF-2 is correlated with poor prognosis and relapse, and that IGF-1R expression was strong in all cases [51]. Furthermore, Tarn and colleagues reported that knockdown of IGF-1R was cytotoxic in GIST-T1 cells [52]. IGFBP3 is the most abundant IGF binding protein in the circulation and is responsible for a majority of IGF transport [53]. Because IGFBP3 has intrinsic IGF-binding activity that can act to sequester IGF from its cognate receptor [13], it is possible that using IGFBP3 as a therapeutic agent would be useful to GIST patients with abnormal IGF expression or IGF-dependent IGF-1R activation. Furthermore, if IGFBP3 is indeed acting through an IGF-dependent mechanism, a difference in the expression levels of IGF or IGF-1R or increased sensitivity to IGF might contribute to the differential IGFBP3- induced effects on cell viability and imatinib response in GIST882 or GIST-T1. Additional studies are needed to determine IGF and IGF-1R expression levels and IGF sensitivity in GIST cell lines and to further examine whether IGFBP3 functions through an IGF-dependent or IGF-independent mechanism in GIST.

In addition to its direct effects on cancer cells, IGFBP3, as a secreted protein, may also have paracrine effects on the tumor environment. Recent studies report that IGFBP3 regulates endothelial cell survival [54] and suppresses angiogenesis $[55,56]$. Thus, it is possible that IGFBP3 further modulates the viability of GIST cells or alters their response to imatinib by targeting endothelial cells or other important cell types, such as macrophages, in the tumor microenvironment. However, the present study is limited to an in vitro cell culture system. Mouse model studies are needed to further investigate whether the effects of IGFBP3 extend to the GIST microenvironment.

\section{Conclusion}

Here, we present evidence that IGFBP3 has dual, opposing effects on GIST cell viability and that IGFBP3 partially mediates the anti-tumor effects of imatinib mesylate in some GISTs in vitro. Further studies are needed to elucidate the mechanisms of IGFBP3 action and to evaluate IGFBP3 as a potential therapeutic agent or target in GISTs.

\section{Methods \\ Reagents}

Imatinib mesylate (Gleevec ${ }^{\mathrm{Tm}}$, Glivec ${ }^{\circledast}$, CGP57148, formerly STI-571) was obtained from Novartis Oncology (East Hanover, NJ). For drug treatment, imatinib was prepared as a $10 \mathrm{mM}$ solution in sterile water and subsequently filter-sterilized using $0.45 \mu \mathrm{m}$ filters (Millipore).

\section{Cell Culture}

The GIST882 cell line was kindly provided by Dr. Jonathan Fletcher (Dana-Farber Cancer Institute, Boston, MA) and was described previously [57]. The GIST-T1 cell line was described previously [58]. Cells were cultured in Dulbecco's minimal essential medium high glucose supplemented with $10 \%$ fetal bovine serum and maintained at $37^{\circ} \mathrm{C}$ in a humidified incubator with $5 \% \mathrm{CO}_{2}$.

\section{IGFBP3 neutralization}

The non-internalizable IGFBP3 blocking antibody, goat polyclonal anti-IGFBP3, was acquired from Diagnostic Systems Laboratories (DSL-R00536, Webster, TX). The corresponding anti-goat IgG (Vector Laboratories, Inc., Burlingame, CA) was used as a control. GIST882 cells were seeded at $4 \times 10^{5}$ cells/well in 6 -well plates and subsequently treated with antibody or IgG alone or in the presence of imatinib for 48 hours before being assayed for changes in cell viability. 


\section{RNA interference}

Knockdown experiments were performed using Ambion Silencer pre-designed siRNA (Ambion, Austin, TX). For IGFBP3 silencing, the selected siRNA (ID \#144575) targets exon 5 and its sequence is given below.

Sense - 5' CGAAGCUUAUUUCUGAGGAtt 3'

\section{Antisense - 5' UCCUCAGAAAUAAGCUUCGtc 3'}

A non-silencing mismatch siRNA, Silencer Negative Control \#1 (AM4635), was used as a negative control. Transfection of siRNA duplexes was performed with Ambion Silencer siPORT NeoFX reagent (AM4510) according to the manufacturer's instructions. Briefly, siRNA was diluted in serum-free minimum essential medium supplemented with non-essential amino acids and NeoFX reagent before mixing with $8 \times 10^{3}$ cells/well in 96-well plates or $2 \times 10^{5}$ cells/well in 6 -well plates. The final concentration of siRNA in the solution was $50 \mathrm{nM}$. After 48 hours, cells were exposed to imatinib for an additional 48 hours before being assayed for changes in cell viability.

\section{ELISA}

GIST882 cells $\left(3 \times 10^{6}\right)$ were treated with imatinib for 24 or 48 hours. After treatment, the conditioned medium was collected and briefly centrifuged to remove the floating cells and cellular debris. Aliquots $(50 \mu \mathrm{L})$ of the supernatant were analyzed for the presence of IGFBP3 using the Human IGFBP3 Quantikine ELISA kit (\#DGB300) from R\&D Systems (Minneapolis, MN) according to the manufacturer's instructions.

\section{Adenovirus-mediated gene transduction}

Adenoviral vectors expressing IGFBP3 (Ad-IGFBP3) or empty vector (Ad-EV) were described previously [47]. For infection of GIST-T1, $8 \times 10^{3}$ cells/well were seeded to 96well plates or $2 \times 10^{5}$ cells/well were seeded to 6 -well plates and allowed to adhere overnight. The following day, cells were mock-infected or infected with the indicated titers of Ad-IGFBP3 or Ad-EV for 2 hours and then incubated in complete medium. The next day, cells were exposed to imatinib for 48 hours before being assayed for changes in cell viability.

\section{MTS assay}

Cell viability was assessed using the 3-(4,5-dimethylthiazol-2-yl)-5-(3-carboxymethoxyphenyl)-2-(4-sulfophe-

nyl)-2H-tetrazolium bromide (MTS) (Promega Corporation, Madison, WI) assay as described previously [59].

\section{Real-time PCR}

Total RNA was isolated from GIST882 cells after siRNA transfection using the Qiagen RNeasy Mini Kit (Valencia, CA). After reverse transcription, real-time PCR was per- formed as described previously [12]. Primers for IGFBP3 (assay ID Hs00181211_m1) and the endogenous control cyclophilin A (gene name PPIA, \#4326316E), as well as TaqMan Universal PCR Master Mix (\#4324018) were obtained from Applied Biosystems (Foster City, CA).

\section{Antibodies}

Primary antibodies used include the following: antiIGFBP3 (DSL-R00536, 1:3000) from Diagnostic Systems Laboratories (Webster, TX) and anti- $\alpha$-tubulin (T5168, 1:5000) from Sigma (St. Louis, MO). Secondary antibodies used include anti-goat (sc-2020, 1:1000) from Santa Cruz (Santa Cruz, CA) and anti-mouse (\#7076, 1:1000) from Cell Signaling (Danvers, MA).

\section{Immunoblotting}

Cells were washed in cold PBS and then incubated in dispersal buffer (PBS + 1 mM EDTA, pH 8) to begin dissociation. Cells were scraped gently, collected, and centrifuged at $2000 \mathrm{rpm}$ for $10 \mathrm{~min}$ before resuspension in cold lysis buffer containing $25 \mathrm{mM}$ HEPES, pH 7.5, 150 $\mathrm{mM} \mathrm{NaCl}, 1 \% \mathrm{NP}-40,10 \mathrm{mM} \mathrm{MgCl}{ }_{2}, 1 \mathrm{mM}$ EDTA, and $10 \%$ glycerol (Upstate, Lake Placid, NY) and supplemented with protease inhibitor cocktail and phosphatase inhibitor cocktails 1 and 2 (1:100) (Sigma, St. Louis, $\mathrm{MO})$. After incubation on ice for 30 minutes and subsequent centrifugation at $14,000 \mathrm{rpm}$ at $4^{\circ} \mathrm{C}$ for 15 minutes, supernatants were collected and protein concentration determined using the Bio-Rad Protein Assay (Bio-Rad, Hercules, CA). Protein $(40 \mu \mathrm{g})$ was resolved by SDS-polyacrylamide gel (8-12\%) electrophoresis, followed by transfer to polyvinylidene fluoride (PVDF) membranes. Membranes were blocked for 1 hour in Tris-buffered saline (TBS) containing 0.05\% Tween 20 (TBS-T) and 5\% nonfat dry milk and probed overnight with primary antibody at $4^{\circ} \mathrm{C}$. After washing several times in TBS-T, membranes were probed with the corresponding horseradish peroxidase (HRP)-conjugated secondary antibody for 1 hour at room temperature. Membranes were washed several times in TBS-T and protein signal detected using ECL (Amersham Biosciences, Piscataway, NJ) or SuperSignal chemiluminescence reagent (Pierce, Rockford, IL).

\section{Statistics}

Values given are mean \pm SEM. Data was analyzed with Student's t-test or two-way ANOVA where indicated. P-values less than 0.05 were considered significant.

\section{Competing interests}

The authors declare that they have no competing interests.

\section{Authors' contributions}

All authors participated in the design of the study. JJD performed all experiments and drafted the manuscript. All authors read, revised, and approved the final manuscript. 


\section{Acknowledgements}

We would like to thank Drs. Pierre McCrea and Funda Meric-Bernstam for their valuable suggestions on the study. This work was supported by an ROI grant (WZ), a career development grant from NIH (JT), and a grant from Commonwealth Foundation for Cancer Research (WZ and JT). JJD is supported by an NIH National Research Service Award (F3 ICAI I 7047).

\section{References}

I. Heinrich MC, Corless CL, Duensing A, McGreevey L, Chen CJ, Joseph N, Singer S, Griffith DJ, Haley A, Town A, Demetri GD, Fletcher CD, Fletcher JA: PDGFRA activating mutations in gastrointestinal stromal tumors. Science 2003, 299:708-7I0.

2. Fletcher CD, Berman JJ, Corless C, Gorstein F, Lasota J, Longley BJ, Miettinen M, O'Leary TJ, Remotti H, Rubin BP, Shmookler B, Sobin LH, Weiss SW: Diagnosis of gastrointestinal stromal tumors: a consensus approach. Int J Surg Pathol 2002, 10:8I-89.

3. Heinrich MC, Corless CL, Demetri GD, Blanke CD, von Mehren M, Joensuu H, McGreevey LS, Chen CJ, Abbeele AD Van den, Druker BJ, Kiese B, Eisenberg B, Roberts PJ, Singer S, Fletcher CD, Silberman S, Dimitrijevic S, Fletcher JA: Kinase mutations and imatinib response in patients with metastatic gastrointestinal stromal tumor. J Clin Oncol 2003, 21:4342-4349.

4. Ng EH, Pollock RE, Munsell MF, Atkinson EN, Romsdahl MM: Prognostic factors influencing survival in gastrointestinal leiomyosarcomas. Implications for surgical management and staging. Ann Surg 1992, 21 5:68-77.

5. DeMatteo RP, Lewis JJ, Leung D, Mudan SS, Woodruff JM, Brennan MF: Two hundred gastrointestinal stromal tumors: recurrence patterns and prognostic factors for survival. Ann Surg 2000, 23 I:5I-58.

6. Verweij J, Casali PG, Zalcberg J, LeCesne A, Reichardt P, Blay JY, Issels R, van Oosterom A, Hogendoorn PC, Van Glabbeke M, Bertulli R, Judson I: Progression-free survival in gastrointestinal stromal tumours with high-dose imatinib: randomised trial. Lancet 2004, 364: I| |27-II34.

7. Savage DG, Antman KH: Imatinib mesylate--a new oral targeted therapy. N Engl J Med 2002, 346:683-693.

8. Heinrich MC, Griffith DJ, Druker BJ, Wait CL, Ott KA, Zigler AJ: Inhibition of c-kit receptor tyrosine kinase activity by STI 57I, a selective tyrosine kinase inhibitor. Blood 2000, 96:925-932.

9. Trent JC, Dupart J, Zhang W: Imatinib Mesylate: Targeted Therapy of Gastrointestinal Stromal Tumor. Curr Can Ther Rev 2005, I:93-108.

10. Blanke CD, Demetri GD, von Mehren M, Heinrich MC, Eisenberg B, Fletcher JA, Corless CL, Fletcher CD, Roberts PJ, Heinz D, Wehre E, Nikolova Z, Joensuu $\mathrm{H}$ : Long-term results from a randomized phase II trial of standard- versus higher-dose imatinib mesylate for patients with unresectable or metastatic gastrointestinal stromal tumors expressing KIT. J Clin Oncol 2008, 26:620-625.

II. Fletcher JA, Rubin BP: KIT Mutations in GIST. Current Opinion in Genetics \& Development 2007, 17:3-7.

12. Trent JC, Ramdas L, Dupart J, Hunt K, Macapinlac H, Taylor E, Hu L, Salvado A, Abbruzzese JL, Pollock R, Benjamin RS, Zhang W: Early effects of imatinib mesylate on the expression of insulin-like growth factor binding protein-3 and positron emission tomography in patients with gastrointestinal stromal tumor. Cancer 2006, 107:1898-1908.

13. Pollak MN, Schernhammer ES, Hankinson SE: Insulin-like growth factors and neoplasia. Nat Rev Cancer 2004, 4:505-5।8.

14. Leal SM, Liu Q, Huang SS, Huang JS: The type $\mathbf{V}$ transforming growth factor beta receptor is the putative insulin-like growth factor-binding protein 3 receptor. J Biol Chem 1997, 272:20572-20576

15. Liu B, Lee HY, Weinzimer SA, Powell DR, Clifford JL, Kurie JM, Cohen P: Direct functional interactions between insulin-like growth factor-binding protein-3 and retinoid $X$ receptoralpha regulate transcriptional signaling and apoptosis. J Biol Chem 2000, 275:33607-336/3.

16. Cao X, Liu W, Lin F, Li H, Kolluri SK, Lin B, Han YH, Dawson MI, Zhang XK: Retinoid X receptor regulates Nur77/TR3-dependent apoptosis [corrected] by modulating its nuclear export and mitochondrial targeting. Mol Cell Biol 2004, 24:9705-9725.
17. Lee KW, Ma L, Yan X, Liu B, Zhang XK, Cohen P: Rapid apoptosis induction by IGFBP-3 involves an insulin-like growth factorindependent nucleomitochondrial translocation of RXRalpha/Nur77. J Biol Chem 2005, 280:16942-16948.

18. Buckbinder L, Talbott R, Velasco-Miguel S, Takenaka I, Faha B, Seizinger BR, Kley N: Induction of the growth inhibitor IGF-binding protein 3 by $\mathbf{p 5 3}$. Nature 1995, 377:646-649.

19. Grimberg A: P53 and IGFBP-3: apoptosis and cancer protection. Mol Genet Metab 2000, 70:85-98.

20. Gucev ZS, Oh Y, Kelley KM, Rosenfeld RG: Insulin-like growth factor binding protein 3 mediates retinoic acid- and transforming growth factor beta2-induced growth inhibition in human breast cancer cells. Cancer Res 1996, 56: I545-I550.

21. Rajah R, Valentinis B, Cohen P: Insulin-like growth factor (IGF)binding protein- 3 induces apoptosis and mediates the effects of transforming growth factor-betal on programmed cell death through a p53- and IGF-independent mechanism. J Biol Chem 1997, 272:12181-12188.

22. Rajah R, Lee KW, Cohen P: Insulin-like growth factor binding protein-3 mediates tumor necrosis factor-alpha-induced apoptosis: role of Bcl-2 phosphorylation. Cell Growth Differ 2002, 13:163-17|.

23. Boyle BJ, Zhao XY, Cohen P, Feldman D: Insulin-like growth factor binding protein-3 mediates I alpha,25-dihydroxyvitamin d(3) growth inhibition in the LNCaP prostate cancer cell line through p2I/WAFI. J Urol 200I, 165:1319-1324.

24. Levitt RJ, Buckley J, Blouin MJ, Schaub B, Triche TJ, Pollak M: Growth inhibition of breast epithelial cells by celecoxib is associated with upregulation of insulin-like growth factor binding protein-3 expression. Biochem Biophys Res Commun 2004, 316:42।-428.

25. Lee KW, Liu B, Ma L, Li H, Bang P, Koeffler HP, Cohen P: Cellular internalization of insulin-like growth factor binding protein3: distinct endocytic pathways facilitate re-uptake and nuclear localization. J Biol Chem 2004, 279:469-476.

26. Hintz RL, Bock S, Thorsson AV, Bovens J, Powell DR, Jakse G, Petrides PE: Expression of the insulin like growth factor-binding protein 3 (IGFBP-3) gene is increased in human renal carcinomas. J Urol 1991, 146: I160-1163.

27. Cheung CW, Vesey DA, Nicol DL, Johnson DW: The roles of IGF$I$ and IGFBP-3 in the regulation of proximal tubule, and renal cell carcinoma cell proliferation. Kidney Int 2004, 65: I 272-I 279.

28. Takaoka M, Harada H, AndI CD, Oyama K, Naomoto Y, Dempsey KL, Klein-Szanto AJ, El-Deiry WS, Grimberg A, Nakagawa H: Epidermal growth factor receptor regulates aberrant expression of insulin-like growth factor-binding protein 3. Cancer Res 2004, 64:77II-7723.

29. Takaoka M, Kim SH, Okawa T, Michaylira CZ, Stairs DB, Johnstone CN, Andl CD, Rhoades B, Lee J], Klein-Szanto AJ, El-Deiry WS, Nakagawa $\mathrm{H}$ : IGFBP-3 regulates esophageal tumor growth through IGF-dependent and independent mechanisms. Cancer Biol Ther 2007, 6:534-540.

30. Jerome L, Alami N, Belanger S, Page V, Yu Q, Paterson J, Shiry L, Pegram M, Leyland-Jones $B$ : Recombinant human insulin-like growth factor binding protein 3 inhibits growth of human epidermal growth factor receptor-2-overexpressing breast tumors and potentiates herceptin activity in vivo. Cancer Res 2006, 66:7245-7252.

31. Vestey SB, Perks CM, Sen C, Calder CJ, Holly JM, Winters ZE: Immunohistochemical expression of insulin-like growth factor binding protein-3 in invasive breast cancers and ductal carcinoma in situ: implications for clinicopathology and patient outcome. Breast Cancer Res 2005, 7:RII9-129.

32. Williams AC, Collard TJ, Perks CM, Newcomb P, Moorghen M, Holly JM, Paraskeva C: Increased p53-dependent apoptosis by the insulin-like growth factor binding protein IGFBP-3 in human colonic adenoma-derived cells. Cancer Res 2000, 60:22-27.

33. Kansra S, Ewton DZ, Wang J, Friedman E: IGFBP-3 mediates TGF beta I proliferative response in colon cancer cells. Int J Cancer 2000, 87:373-378.

34. Martin JL, Pattison SL: Insulin-like growth factor binding protein-3 is regulated by dihydrotestosterone and stimulates deoxyribonucleic acid synthesis and cell proliferation in LNCaP prostate carcinoma cells. Endocrinology 2000, | 4 I:240I-2409.

35. Fowler CA, Perks CM, Newcomb PV, Savage PB, Farndon JR, Holly JM: Insulin-like growth factor binding protein-3 (IGFBP-3) 
potentiates paclitaxel-induced apoptosis in human breast cancer cells. Int / Cancer 2000, 88:448-453.

36. Guix M, Faber AC, Wang SE, Olivares MG, Song Y, Qu S, Rinehart $C$ Seidel B, Yee D, Arteaga CL, Engelman JA: Acquired resistance to EGFR tyrosine kinase inhibitors in cancer cells is mediated by loss of IGF-binding proteins. J Clin Invest 2008, I 1 8:2609-26I9.

37. Lee DY, Yi HK, Hwang PH, Oh Y: Enhanced expression of insulin-like growth factor binding protein-3 sensitizes the growth inhibitory effect of anticancer drugs in gastric cancer cells. Biochem Biophys Res Commun 2002, 294:480-486.

38. Granata R, Trovato L, Garbarino G, Taliano M, Ponti R, Sala G, Ghidoni $R$, Ghigo $E$ : Dual effects of IGFBP-3 on endothelial cell apoptosis and survival: involvement of the sphingolipid signaling pathways. FASEB J 2004, I8: |456-1458.

39. Cobb LJ, Liu B, Lee KW, Cohen P: Phosphorylation by DNAdependent protein kinase is critical for apoptosis induction by insulin-like growth factor binding protein-3. Cancer Res 2006, 66: 10878-10884.

40. Santer FR, Bacher N, Moser B, Morandell D, Ressler S, Firth SM, Spoden GA, Sergi C, Baxter RC, Jansen-Durr P, Zwerschke W: Nuclear insulin-like growth factor binding protein-3 induces apoptosis and is targeted to ubiquitin/proteasome-dependent proteolysis. Cancer Res 2006, 66:3024-3033.

4I. Burrows C, Holly JM, Laurence NJ, Vernon EG, Carter JV, Clark MA, Mclntosh J, McCaig C, Winters ZE, Perks CM: Insulin-like growth factor binding protein 3 has opposing actions on malignant and nonmalignant breast epithelial cells that are each reversible and dependent upon cholesterol-stabilized integrin receptor complexes. Endocrinology 2006, 1 47:3484-3500.

42. Huang SS, Ling TY, Tseng WF, Huang YH, Tang FM, Leal SM, Huang JS: Cellular growth inhibition by IGFBP-3 and TGF-betal requires LRP-I. FASEB I 2003, I 7:2068-208I.

43. Fanayan S, Firth SM, Butt AJ, Baxter RC: Growth inhibition by insulin-like growth factor-binding protein-3 in T47D breast cancer cells requires transforming growth factor-beta (TGFbeta) and the type II TGF-beta receptor. J Biol Chem 2000, 275:39|46-39|5I.

44. Schwarze SR, DePrimo SE, Grabert LM, Fu VX, Brooks JD, Jarrard DF: Novel pathways associated with bypassing cellular senescence in human prostate epithelial cells. J Biol Chem 2002, 277: I 4877-I 4883

45. Chang YS, Wang L, Suh YA, Mao L, Karpen SJ, Khuri FR, Hong WK, Lee HY: Mechanisms underlying lack of insulin-like growth factor-binding protein-3 expression in non-small-cell lung cancer. Oncogene 2004, 23:6569-6580.

46. Prieur A, Tirode F, Cohen P, Delattre O: EWS/FLI-I silencing and gene profiling of Ewing cells reveal downstream oncogenic pathways and a crucial role for repression of insulin-like growth factor binding protein 3. Mol Cell Biol 2004, 24:7275-7283.

47. Lee HY, Chun KH, Liu B, Wiehle SA, Cristiano RJ, Hong WK, Cohen $P$, Kurie JM: Insulin-like growth factor binding protein-3 inhibits the growth of non-small cell lung cancer. Cancer Res 2002, 62:3530-3537.

48. Cohen P, Rajah R, Rosenbloom J, Herrick DJ: IGFBP-3 mediates TGF-betal-induced cell growth in human airway smooth muscle cells. Am J Physiol Lung Cell Mol Physiol 2000, 278:L545-55I.

49. Rocha RL, Hilsenbeck SG, Jackson JG, Lee AV, Figueroa JA, Yee D: Correlation of insulin-like growth factor-binding protein-3 messenger RNA with protein expression in primary breast cancer tissues: detection of higher levels in tumors with poor prognostic features. I Natl Cancer Inst 1996, 88:60 I-606.

50. Xi Y, Nakajima G, Hamil T, Fodstad O, Riker A, Ju J: Association of insulin-like growth factor binding protein-3 expression with melanoma progression. Mol Cancer Ther 2006, 5:3078-3084.

5I. Braconi C, Bracci R, Bearzi I, Bianchi F, Sabato S, Mandolesi A, Belvederesi L, Cascinu S, Valeri N, Cellerino R: Insulin-like growth factor (IGF) I and 2 help to predict disease outcome in GIST patients. Ann Oncol 2008, 19:1293-1298.

52. Tarn C, Rink L, Merkel E, Flieder D, Pathak H, Koumbi D, Testa JR, Eisenberg B, von Mehren M, Godwin AK: Insulin-like growth factor I receptor is a potential therapeutic target for gastrointestinal stromal tumors. Proc Natl Acad Sci USA 2008, 105:8387-8392.
53. Rajaram S, Baylink DJ, Mohan S: Insulin-like growth factor-binding proteins in serum and other biological fluids: regulation and functions. Endocr Rev 1997, I 8:801-83I.

54. Franklin SL, Ferry RJ Jr, Cohen P: Rapid insulin-like growth factor (IGF)-independent effects of IGF binding protein-3 on endothelial cell survival. J Clin Endocrinol Metab 2003, 88:900-907.

55. Oh SH, Kim WY, Kim JH, Younes MN, El-Naggar AK, Myers JN, Kies $M$, Cohen $P$, Khuri F, Hong WK, Lee HY: Identification of insulinlike growth factor binding protein-3 as a farnesyl transferase inhibitor SCH66336-induced negative regulator of angiogenesis in head and neck squamous cell carcinoma. Clin Cancer Res 2006, 12:653-661.

56. Liu B, Lee KW, Anzo M, Zhang B, Zi X, Tao Y, Shiry L, Pollak M, Lin $S$, Cohen $P$ : Insulin-like growth factor-binding protein-3 inhibition of prostate cancer growth involves suppression of angiogenesis. Oncogene 2007, 26:1811-1819.

57. Tuveson DA, Willis NA, Jacks TA, Griffin JD, Singer S, Fletcher $C D$, Fletcher JA, Demetri GD: STI57I inactivation of the gastrointestinal stromal tumor c-KIT oncoprotein: biological and clinical implications. Oncogene 200I, 20:5054-5058.

58. Taguchi T, Sonobe H, Toyonaga S, Yamasaki I, Shuin T, Takano A, Araki K, Akimaru K, Yuri K: Conventional and molecular cytogenetic characterization of a new human cell line, GIST. TI, established from gastrointestinal stromal tumor. Lab Invest 2002, 82:663-665.

59. Choi W, Gerner EW, Ramdas L, Dupart J, Carew J, Proctor L, Huang P, Zhang W, Hamilton SR: Combination of 5-fluorouracil and NI, Ni I-diethylnorspermine markedly activates spermidine/spermine $\mathrm{NI}$-acetyltransferase expression, depletes polyamines, and synergistically induces apoptosis in colon carcinoma cells. J Biol Chem 2005, 280:3295-3304.
Publish with Biomed Central and every scientist can read your work free of charge

"BioMed Central will be the most significant development for disseminating the results of biomedical research in our lifetime. "

Sir Paul Nurse, Cancer Research UK

Your research papers will be:

- available free of charge to the entire biomedical community

- peer reviewed and published immediately upon acceptance

- cited in PubMed and archived on PubMed Central

- yours - you keep the copyright
BioMedcentral 